\title{
KEEFEKTIFAN METODE TIME TOKEN ARENDS DAN MIND MAPPING DALAM MENULIS TEKS EKSPOSISI
}

\author{
Septi Dwi Ernawati ${ }^{1}$, Prasetyo Yuli Kurniawan ${ }^{* 2}$, Ubaedillah $^{3}$ \\ 1,2,3Program Studi Pendidikan Bahasa dan Sastra Indonesia, Fakultas Keguruan dan Ilmu \\ Pendidikan, Universitas Muhadi Setiabudi Brebes, Indonesia \\ e-mail corresponden: *prasetyoyulikurniawan@gmail.com
}

\begin{abstract}
Abstrak
Penelitian ini bertujuan untuk mendeskripsikan metode Time Token Arends terhadap hasil belajar menulis teks eksposisi, untuk mendeskripsikan metode Mind Mapping terhadap hasil belajar menulis teks eksposisi, dan untuk mendeskripsikan yang lebih efektif antara dua metode tersebut terhadap hasil belajar menulis teks eksposisi pada peserta didik kelas X SMA Negeri 1 Wanasari. Jenis penelitian yang digunakan adalah Ekperimen semu yang menggunakan desain posttest control group. Sampel yang digunakan dalam penelitian ini yaitu kelas X MIPA 1 sebagai kelas eksperimen I dan kelas X MIPA 3 sebagai eksperimen II. Diperoleh hasil penelitian dari kedua kelas eksperimen tersebut yaitu, rata-rata hasil belajar menulis teks eksposisi menggunakan metode time token arends sebesar 82,56, sedangkan rata-rata hasil menulis teks eksposisi menggunakan metode mind mapping sebesar 76,64. Hasil analisis statistik menunjukan bahwa nilai signifikasi yang diperoleh $t_{\text {hitung }} 2,930>t_{\text {tabel }} 1,714$. Dapat disimpulkan bahwa metode time token arends lebih efektif dari pada metode mind mapping terhadap hasil belajar menulis teks eksposisi pada peserta didik kelas X SMA Negeri 1 Wanasari.
\end{abstract}

Kata Kunci: Metode Time Token Arends, Metode Mind Mapping, Menulis Teks Eksposisi.

\begin{abstract}
The purpose of this research are to discribe of the methods of thime token arends through the students achivment of writing exposition text of the tenth students of senior high school 1 Wanasari, to describe of the methods ofmind mapping through the students achivment of writing exsposition text, and to describe the more effectivemethods between both of then through tenth the students' achivment of writing exsposition text at the tenth grade students of senior high school 1 Wanasari. The type of research used is a quasiexperiment using the design of the posttest control group. The sample used in this study is class X MIPA 1 as experimental I and class X MIPA 3 as experiment II. The results of the two experimental classes were obtained, namely, the average learning outcomes of writing exposition text using the time token arends method of 82.56, while the average result of exposition text writing using the mind mapping method was 76.64. The results of statistical analysis show that the significance value obtained is thitung 2.930>t table 1.714. It can be concluded that the time token arends method is more effective than the mind mapping method for the learning outcomes of writing exposition text in class $X$ students of senior high school 1 Wanasari.
\end{abstract}

Keywords: Time Token Arends Method, Mind Mapping Method, Text Eksposition Writing.

\section{PENDAHULUAN}

Dalam pembelajaran bahasa Indonesia tentu keempat keterampilan harus dimiliki oleh peserta didik agar pembelajaran menjadi lebih efektif. Dari keempat keterampilan tersebut terdapat keterampilan menulis yang merupakan suatu keterampilan berbahasa yang salah 
satunya sangat dipentingkan. Menulis merupakan suatu kegiatan yang produktif dan ekspresif[1].

Kecenderungan di lapangan ada peserta didik kurang berminat, sehingga sulit belajar menulis kreatif karena guru sebagai seorang pendidik terutama guru Bahasa Indonesia jarang memberikan pelajaran menulis[2]. Arah pembelajaran keterampilan menulis di SMA berdasarkan Kurikulum 2013 lebih dititikberatkan pada tingkat kreativitas dan daya pikir kritis peserta didik dalam mengembangkan ide dan gagasannya sesuai konteks.

Berdasarkan hasil observasi dan wawancara dengan guru bahasa Indonesia kelas $\mathrm{X}$ SMA Negeri 1 Wanasari, peneliti menemukan permasalahan khususnya pada keterampilan menulis pada peserta didik.Pada pembelajaran bahasa Indonesia materi teks eksposisi, pembelajaran tersebut salah satu keterampilan berbahasa Indonesia yang merupakan jenis keterampilan menulis yang harus dikuasai. Untuk nilai KKM bahasa Indonesia adalah 75, sedangkan dilihat dari ulangan yang dilakukan guru pada pembelajaran teks eksposisi tidak tuntas mencapai nilai KKM. 34 peserta didik dari satu kelas hanya satu peserta didik yang mendapatkan nilai mencapai 90 pada ulangan teks eksposisi, sedangkan peserta didik yang lain mendapatkan nilai 60, 65 sampai 70 .

Pembelajaran menulis teks eksposisi di sekolah, pada kenyataannya masih menemui kendala [3]. Teks eksposisi yang dihasilkan oleh peserta didik masih jauh dari harapan. Pada saat peserta didik menulis teks eksposisi, peserta didik kesulitan dalam menentukan dan mengembangkan ide menjadi karangan eksposisi yang utuh, kesulitan membuat kalimat yang baik, sehingga teks yang dihasilkan menjadi kurang bermakna dan sulit dipahami.
Faktor yang mempengaruhi rendahnya hasil belajar peserta didik pada pembelajaran menulis teks eksposisi yakni sebagian besar peserta didik kesulitan dalam mencari bahan atau contoh untuk menulis teks eksposisi, selain itu guru hanya menyampaikan teori masih dengan metode ceramah dan penugasan. Kurangnya pemanfaatan media pembelajaran yang digunakan. penggunaan media buku paket dan proyektor sebagai sarana pembelajaran terus dilakukan.

Penggunaan strategi maupun metode yang digunakan dalam pembelajaran harus lebihbervariasi.Metode pembelajaran yang digunakan pada pelajaran bahasa Indonesia harus lebih interaktif, kreatif, inovatif, dapat menumbuhkan potensi peserta didik agar dapat berpikir kritis, dan menghindari cara pengajaran yang berpusat pada pendidik atau cara pengajaran yang hanya memberikan penjelasan secara verbal. Metode pembelajaran akan membuat kelas lebih hidup dan tidak seperti kegiatan pembelajaran terdahulu yang masih konvensional, hal ini tentu membuat peserta didik menjadi pasif.

Penggunakanmetode Time Token Arends dan metode Mind Mapping terhadap hasil belajar menulis teks eksposisi pada peserta didik. menurut [4]Metode time token arends adalah metode pembelajaran untuk melatih dan mengembangkan keterampilan sosial, agar peserta didik tidak mendominasi pembicaraan atau diam sama sekali. Sedangkan metode mind mapping dikembangkan sebagai metode efektif untuk mengembangkan gagasangagasan melalui rangkaian peta-peta. Salah satu penggagas metode ini adalah Buzan[5].

Penelitian ini bertujuan untuk memperbaiki praktik pembelajaran 
Jurnal SEMANTIKA, Volume 1, No. 01, Agustus 2019, p. 55-62

keterampilan menulis, secara khusus bertujuan untuk mendeskripsikan hasil belajar menulis teks eksposisi dengan menggunakan metode Time Token Arends pada peserta didik kelas X SMA Negeri 1 Wanasari, untuk mendeskripsikan hasil belajar menulis teks eksposisi dengan menggunakan metode Mind Mapping pada peserta didik kelas X SMA Negeri 1 Wanasari, untuk mendeskripsikan yang lebih efektif antara metode Time Token Arends dan metode Mind Mapping terhadap hasil belajar menulis Teks Eksposisi pada peserta didik kelas X SMA Negeri 1 Wanasari.

\section{KAJIAN TEORI}

\section{Metode Pembelajaran}

Metode pembelajaran merupakan suatu alat dalam pelaksanaan pendidikan, yakni yang digunakan dalam penyampaian materi tersebut [6]. Materi pelajaran yang mudah pun kadangkadang sulit berkembang dan sulit diterima oleh peserta didik, karena cara atau metode yang digunakannya kurang tepat. Namun, sebaliknya suatu pelajaran yang sulit akan mudah diterima oleh peserta didik, karena penyampaian dan metode yang digunakan mudah dipahami, tepat dan menarik.

Adanya hasil belajar siswa yang tinggi dan berkualitas, dapat dihasilkan dari proses pembelajaran yang berkualitas, untuk menghasilkan proses pembelajaran yang berkualitas seorang tenaga pendidik membutuhkan kemampuan dalam menerapkan metode pembelajaran yang sesuai dengan kebutuhan dalam kelas, ketidaksesuaian metode pembelajaran yang diterapkan dapat menurunkan kualitas proses pembelajaran itu sendiri[7].

Metode pembelajaran adalah rencana atau cara yang digunakan dalam melakukan kegiatan untuk mencapai tujuan pembelajaran. Dengan adanya kurikulum 2013 perkembangan metode pembelajaran kini sangat bervariasi. Mengharuskan guru untuk lebih berinovasi dalam pembelajaran, agar hasil belajar peserta didik lebih meningkat. Berbagai macam metode pembelajaran, peneliti mengambil jenis metode Time Token Arends dan metode Mind Mapping untuk diterapkan pada pembelajaran menulis teks eksposisi.

Metode time token arends digunakan dengan melakukan diskusi kelompok untuk menentukan atau mencari informasi dari suatu materi dan selanjutnya akan didiskusikan secara bersama dalam kelas. Proses penyampaian pendapat dilakukan dengan cara memberikan kupon berbicara yang telah diberikan guru \pm 1 menit per kupon pada tiap peserta didik.

Sedangkan metode mind mapping dimulai dengan menulis gagasan utama ditengah halaman agar dapat membentangkannya ke seluruh arah untuk menciptakan semacam diagram yang terdiri dari kata kunci-kata kunci, frasa-frasa, konsep-konsep, fakta-fakta, dan gambar-gambar. Setelah mencari atau menemukan informasi dan telah ditentukan menjadi mind mapping selanjutnya perwakilan dari anggota kelompok memaparkan hasil dari diskusi materi yang telah diberikan tersebut.

\section{Keterampilan Menulis}

Kegiatan menulis adalah suatu keterampilan produktif dalam pembelajaran bahasa, karena kegiatan tersebut lebih banyak menekankan pada penuangan ide dan gagasan dalam bentuk kata-kata, susunan kalimat, dan menjadi suatu gagasan alenia[8].

Keterampilan menulis dalam pembelajaran adalah suatu hal yang penting. Hal ini seperti yang diungkap [1], bahwa keterampilan menulis berfungsi sebagai alat komunikasi secara 
tidak langsung, tidak secara tatap muka dengan orang lain. Dalam kegiatan menulis ini, penulis harus terampil memanfaatkan grafologi, struktur bahasa dan kosa kata. Selain itu, keterampilan menulis ini tidak akan datang secara otomatis, tetapi harus melalui latihan dan praktik yang bannyak dan teratur.

Dari pendapat para ahli dapat disimpulkan bahwa keterampilan menulis adalah kemampuan yang dimiliki seseorang dengan berlatih, selalu mempraktikan, dan memiliki penguasaan kosa kata.

\section{Teks Eksposisi}

Menurut peneliti [9] teks eksposisi adalah sebuah teks atau paragraf yang di dalamnya berisi sejumlah informasi dan pengetahuan dengan gaya penulisan sigkat, padat dan akurat.

Sedangkan menurut peneliti [8] teks eksposisi ditulis dengan tujuan untuk: (1) Memberi informasi mengenai suatu objek; (2) Memberitahu, mengupas, menguraikan atau menerangkan sesuatu; (3) Menyajikan fakta dan gagasan; dan (4) Menjelaskan hakikat sesuatu, memberi petunjuk untuk mencapai sesuatu[3]. Untuk itu, agar pembaca mendapatkan pemahaman yang baik dan benar, penulisan karangan teks eksposisi harus utuh dan padu. Hal ini bertujuan agar pesan atau sesuatu yang ingin dijelaskan penulis dapat sampai kepada pembaca.

\section{METODE PENELITIAN}

\section{Tempat penelitian}

Tempat penelitian di SMA Negeri 1 Wanasari Jl. Pebatan desa Sidamulya Kecamatan Brebes. Kabupaten Brebes.

\section{Jenis Penelitian}

Penelitian ini termasuk dalam jenis penelitian eksperimen semu. Bentuk penelitian yang dipergunakan ialah posttest control group. Peneliti menggunakan dua kelompok dimaksudkan untuk menjadi kelompok pembanding antara kelompok yang mendapat perlakuan. Kedua kelompok tersebut mendapat perlakuan dan mengerjakan tes yang sama yaitu postes.

\section{Definisi Operasional Variabel}

Definisi operasional variabel yang digunakan dalam penelitian ini sebagai berikut.

1. variabel independen (bebas) dan variabel dependen (terikat).

Variabel Independen (bebas).

Variabel independen adalah variabel yang (mungkin) menyebabkan, atau mempengaruhi hasil. Variabel independen (bebas) yang digunakan dalam penelitian ini yakni metode time token arends dan metode mind mapping [10].

Variabel Dependen (terikat).

Variabel dependen adalah variabel yang bergantung pada variabel independen, atau hasil dari pengaruh variabel independen. Variabel dependen (terikat) yang digunakan dalam penelitian ini yakni menulis teks eksposisi[10].

2. Devinisi operasional variabel

a. Menulis adalah suatu keterampilan berbahasa yang digunakan untuk berkomunikasi secara tidak langsung, tidak secara tatap muka dengan orang lain[1].

b. Metode time token arends merupakan salah satu contoh kecil dari penerapan pembelajaran demokratis di sekolah, proses pembelajaran yang demokratis adalah proses belajar yang menempatkan peserta didik sebagai subjek[5].

c. Metode mind mapping adalah pengembangan gagasan-gagasan melalui rangkaian peta-peta.. Untuk membuat mind mapping, menurut Buzan dalam[5] seseorang biasanya 
memulainya dengan menulis gagasan utama di tengah halaman dan dari situlah, ia bisa membentangkannya ke seluruh arah atau menciptakan semacam diagram yang terdiri dari kata kunci-kata kuci, frasa-frasa, konsep-konsep, fakta-fakta, dan gambar-gambar.

\section{Teknik Pengumpulan Data}

pengumpulan data dapat dilakukan dalam berbagai setting, berbagai sumber, dan berbagai cara[15]. Bila dilihat dari setting-nya, data dapat dikumpulkan pada setting alamiah (natural setting), pada laboratorium dengan metode eksperimen, di rumah dengan berbagai responden, pada suatu seminar, diskusi, di jalan dan lain-lain. Pengumpulan data yaitu sebagai berikut.

\section{Observasi}

Observasi yang dilakukan sesuai dengan rancangan, objek yang akan diamati, kapan dan dimana tempatnya. Dalam melakukan observasi peneliti tahu dengan pasti tentang variabel yang akan diamati.

2. Wawancara

Wawancara digunakan sebagai teknik pengumpulan data untuk menemukan permasalahan yang harus diteliti, dan juga untuk engetahui hal-hal dari responden yang lebih mendalam.

\section{Tes}

Tes yang digunakan dalam hal ini yaitu berupa posttest, yang digunakan setelah pembelajaran usai. Dalam hal ini untuk mengetahui hasil dari pengetahuan peserta didik selama mengikuti pembelajaran teks eksposisi.

\section{InstrumenPenelitian}

Instrumen yang digunakan dalam penelitian ini adalah instrumen tes. Tes yang digunakan adalah tes hasil belajar peserta didik dalam menulis teks eksposisi. Tes ini dikerjakan oleh peserta didikkedua kelompok eksperimen. Tes yang diberikan kepada dua kelompok tersebut berupa posttest. posttest dilaksanakan setelah eksperimen.

\section{Teknik Analisis Data}

Teknik analisis data penelitian ini berupa uji kenormalan data, uji kehomogenitas data, dan uji hipotesis (perbedaan dua rata-rata). Selengkapnya dijelaskan sebagai berikut.

a. Uji Kenormalan Data

Uji normalitas dilakukan terhadap skor posttest kelompok eksperimen I dan Kelompok eksperimen II. Pengujian ini menggunakan teknik statistik Kolmogorov Smirnov. Perhitungan ini menggunakan bantuan program komputer SPSS 22.

b. Uji Kehomogenitas Data

Uji homogenitas dimaksudkan untuk mengetahui kesamaan beberapa sampel, yaitu seragam tidaknya sampelsampel yang diambil dari populasi yang sama. Untuk menguji homogenitas varian tersebut perlu dilakukan uji statistik (test of variance) pada distribusi skor kelompok yang bersangkutan. Uji homogenitas dalam perhitungan ini menggunakan bantuan program komputer SPSS 22.

c. Uji Hipotesis

Jika data dinyatakan normal dan homogen selanjutnya dilakukan uji hipotesis. Uji hipotesis atau perbedaan dua rata-rata hitung dari dua sempel pada hakikatnya merupakan uji dari dua distribusi rata-rata hitung. Untuk maksud itu diperlukan alat taksir untuk mengetes ada atau tidaknya perbedaan rata-rata hitung tersebut dan didapatkannya nilai signifikasi pada uji tersebut. Uji hipotesis ini menggunakan bantuan program komputer SPSS 22.

\section{HASIL DAN PEMBAHASAN}

1. Hasil Belajar Menulis Teks Eksposisi dengan Menggunakan Metode Time Token Arends pada 
Jurnal SEMANTIKA, Volume 1, No. 01, Agustus 2019, p. 55-62

\section{Peserta Didik Kelas X SMA Negeri 1 Wanasari.}

Perolehan nilai teks eksposisi pada tes akhir (postes) dengan menggunkan metode time token arends kelas eksperimen I (MIPA I) SMA Negeri 1 Wanasari dapat dilihat pada tabel berikut ini.

Tabel 1. Perolehan Nilai Postes Kelas

Eksperimen I dengan Metode Time

\begin{tabular}{|c|c|c|c|}
\hline \multicolumn{4}{|c|}{ Token Arends } \\
\hline No & $\begin{array}{c}\text { Rentang } \\
\text { Nilai }\end{array}$ & Kategori & $\begin{array}{c}\text { Jumlah } \\
\text { Peserta } \\
\text { Didik }\end{array}$ \\
\hline 1. & $89-100$ & $\begin{array}{l}\text { Sangat } \\
\text { Baik }\end{array}$ & 4 \\
\hline 2. & $77-88$ & Baik & 15 \\
\hline 3. & $73-76$ & Cukup & 3 \\
\hline 4. & $00-72$ & Kurang & 3 \\
\hline
\end{tabular}

Berdasarkan pada tabel diatas dapat dikemukakan bahwa hasil postes kelas eksperimen I yang dilaksanakan dengan menggunakan metode time token arends yaitu perolehan nilai terendah 72 dan perolehan nilai tertinggi 92. Perolehan nilai tersebut dapat dilihat dari rentang nilai tabel diatas yaitu pencapaian rentang nilai 00-72 sebanyak 3 peserta didik yang belum tuntas, 73-76 sebanyak 3 peserta didik dengan kategori cukup, 77-88 sebanyak 15 peserta didik dengan kategori baik, dan 89-100 sebanyak 4 peserta didik dengan kategori sangat baik.

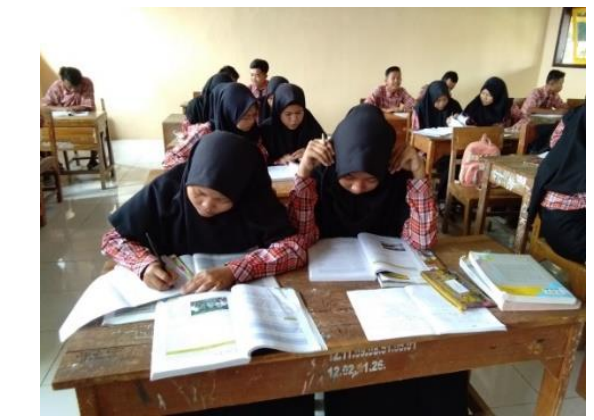

Gambar 1. Postes teks eksposisi dengan metode pembelajaran time token arends.
2. Hasil Belajar Menulis Teks Eksposisi dengan Menggunakan Metode Mind Mapping pada Peserta Didik Kelas X SMA Negeri 1 Wanasari.

Perolehan nilai teks eksposisi pada tes akhir (postes) dengan menggunkan metode mind mapping kelas eksperimen II (MIPA 3) SMA Negeri 1 Wanasari dapat dilihat pada tabel berikut ini.

Tabel 2. Perolehan Nilai Postes Kelas Eksperimen II dengan Metode Mind

\begin{tabular}{cccc}
\multicolumn{4}{c}{ Mapping } \\
\hline No & $\begin{array}{c}\text { Rentang } \\
\text { Nilai }\end{array}$ & Kategori & $\begin{array}{c}\text { Jumlah } \\
\text { Peserta } \\
\text { Didik }\end{array}$ \\
\hline 1. & $89-100$ & $\begin{array}{c}\text { Sangat } \\
\text { Baik }\end{array}$ & 1 \\
& & Baik & 10 \\
2. & $77-88$ & Cukup & 13 \\
3. & $61-76$ & Kurang & 1 \\
4. & $00-60$ & Jumlah & 25 \\
\hline \multicolumn{4}{c}{}
\end{tabular}

Berdasarkan pada tabel diatas dapat dikemukakan bahwa hasil postes kelas eksperimen II yang dilaksanakan dengan menggunakan metode mind mapping yaitu perolehan nilai terendah 60 dan perolehan nilai tertinggi 92. Perolehan nilai tersebut dapat dilihat dari rentang nilai tabel diatas yaitu pencapaian rentang nilai 00-60 hanya 1 peserta didik yang belum tuntas, 61-76 sebanyak 13 peserta didik dengan kategori cukup, 7788 sebanyak 10 peserta didik dengan kategori baik, dan 89-100 sebanyak hanya 1 peserta didik dengan kategori sangat baik.

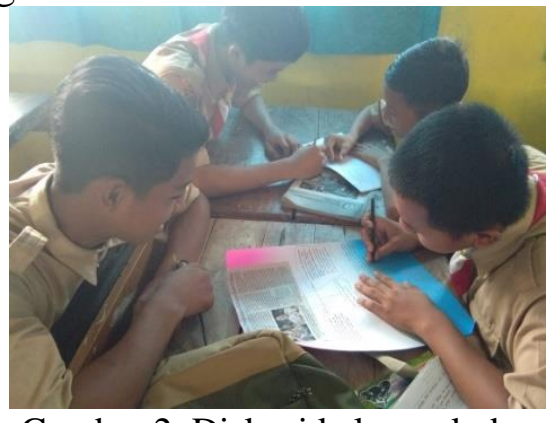

Gambar 2. Diskusi kelompok dan pembuatan mind mapping 
Jurnal SEMANTIKA, Volume 1, No. 01, Agustus 2019, p. 55-62

\section{Keefektifan Menulis Peserta Didik dalam Pembelajaran Teks Eksposisi dengan Menggunakan Metode Time Token Arends dan Metode Mind Mapping.}

Berdasarkan penelitian yang dilakukan pada kelas eksperimen I (X MIPA 1) yang diajar dengan metode pembelajaran Time Token Arends dan kelas eksperimen II (X MIPA 3) yang diajar dengan metode pembelajaran Mind Mapping memiliki tingkat keefektifannya masing-masing sebagai tes kemampuan untuk mengetahui hasil belajar peserta didik sekaligus tingkat penguasaan materi peserta didik terhadap kemampuan menulis teks eksposisi. Metode yang digunakan sangat mempengaruhi proses dalam pembelajaran. Terlihat dari perbandingan rata-rata hasil pembelajaran menulis teks eksposisi dengan menggunakan metode tersebut. Bahwa rata-rata hasil menulis teks eksposisi dengan menggunakan metode time token arends lebih tinggi dari pada metode mind mapping yang berkategori sedang. Pengaruh metode pembelajaran sangat besar bagi guru maupun peserta didik. Adanya inovasi metode yang digunakan dalam kegiatan pembelajaran yang dilakukan oleh guru membuat peserta didik lebih bersemangat dan mampu mengikuti pembelajaran dengan aktif.

Dari peroleh hasil belajar menulis teks ekposisi kelompok eskperimen I yang diajar dengan metode pembelajaran time token arends lebih tinggi dibandingkan kelompok eksperimen II yang menggunakan dengan metode pembelajaran mind mapping. Hal ini disebabkan karena dalam metode pembelajaran time token arends, peserta didik diberi kesempatan yang sama untuk menjawab, bertanya, serta memberi tanggapan pada saat proses pembelajaran berlangsung, dan setiap peserta didik harus menggunakan kesempatan tersebut sebagai tindakan untuk memperoleh nilai kelompok.

Hal tersebut sejalan dengan penelitian yang dilakukan[12] Penelitian menunjukkan bahwa respon peserta didik terhadap penerapan metode pembelajaran Time Token Arends menunjukan respon positif dan mampu membuat semua peserta didik terlibat aktif dalam pembelajaran.Sama halnya dengan penelitian yang dilakukan [13] pembelajaran dengan metode belajar menggunakan model pembelajaran time token arends pada mata pelajaran Bahasa Indonesia memiliki dampak positif dalam meningkatkan kinerja guru yang ditandai dengan peningkatan ketuntasan belajar peserta didik. Metode pembelajaran digunakan agar proses kegiatan belajar lebih memberikan warna atau suasana kelas yang berbeda, hal ini juga dapat memberikan dampak positif bagi peserta didik untuk mendapatkan informasi yang lebih mudah dipahami maupun didapat dari pembelajaran.

Metode mind mapping juga membantu proses pembelajaran peserta didik dalam melakukan research dan juga penemuan suatu penyeselaian masalah sesuai dengan informasi yang didapat. Mind map adalah cara termudah untuk menempatkan informasi ke dalam otak dan mengambil informasi ke luar dari otak[14]. Mind map adalah cara mencatat yang kreatif, efektif, dan secara harfiah akan memetakan pikiran-pikiran kita.

Sejalan dengan penelitian yang dilakukan [15] menyatakan metode mind mapping (Peta Pikiran) sebenarnya bukanlah hal baru. Dalam dunia pendidikan, sistem ini telah digunakan bertahun-tahun. Cara kerja pikiran manusia (secara alami) adalah memancar dari satu titik 
Jurnal SEMANTIKA, Volume 1, No. 01, Agustus 2019, p. 55-62

pikiran ke berbagai asosiasi pemikiran yang lain dan selalu menyebar kembali dengan tidak terbatas atau diistilahkan dengan Radiant Thinking.

Sejalan penelitian tersebut, pengembangan media puzzle juga dapat meningkatkan hasil belajar peserta didik[16]. Peserta didik dapat meningkatkan pengetahuan dan ketrampilan dalam berpikir melalui permainan dalam pembelajaran. Sehingga pembelajaran lebih menarik dan mudah untuk dipahami.

Berdasarkan penelitian yang dilakukan pada kelas eksperimen I (X MIPA 1) yang diajar dengan metode pembelajaran Time Token Arends dan kelas eksperimen II (X MIPA 3) yang diajar dengan metode pembelajaran Mind Mapping memiliki tingkat keefektifannya masing-masing sebagai tes kemampuan untuk mengetahui hasil belajar peserta didik sekaligus tingkat penguasaan materi peserta didik terhadap kemampuan menulis teks eksposisi.Metode yang digunakan sangat mempengaruhi proses dalam pembelajaran. Terlihat dari perbandingan rata-rata hasil pembelajaran menulis teks eksposisi dengan menggunakan metode time token arends dan metode mind mapping.

\section{SIMPULAN}

Berdasarkan hasil penelitian dan pembahasan pada penelitian ini, makadiperoleh Hasil belajar peserta didik pada mata pelajaran teks eksposisiyang diajar menggunakan metode pembelajaran time token arends memperoleh nilai rata-rata 82,56 yang termasuk pada kategori tinggi. Sedangkan Hasil belajar peserta didikpada mata pelajaran teks eksposisi yang diajar menggunakan metode pembelajaran mind mappingmemperoleh nilai rata-rata
76,64 yang termasuk pada kategori sedang.

Dari hasil tes belajar kedua kelompok tersebut, dilakukan uji normalitas, uji homogenitas, dan uji hipotesis. Dari uji normalitas dengan hasil post-test harus memperoleh hasil lebih dari 0,05 atau sig-hitung > sig.tabel diperoleh kelompok eksperimen I (X IPA 1) adalah 0,053 sehingga $(0,053>0,05)$, untuk data posttest kelompok eksperimen II (X IPA 3) adalah 0,056 sehingga $(0,056>0,05)$. Sedangkan uji homogenitas menunjukkan bahwa kedua kelompok eksperimen berdistribusi homogen dengan menunjukan hasil nilai signifikasi sebesar 0,803, sehingga dapat diartikan nilai postes peserta didik homogen karena nilai 0,803 >0,05. Pada pengujian hipotesis dengan menggunakan uji t-test sampel independen, dimana data yang diuji yaitu data hasil post-test kedua kelompok. Berdasarkan hasil perhitungan maka diperoleh nilai $t_{\text {hitung }}$ sebesar 2,930 diperoleh nilai $t_{\text {tabel }}$ sebesar 1,714. Berdasarkan hasil analisis data nilai $t_{\text {hitung }}>t_{\text {tabel }}$ yaitu $(2,930>1,714)$. Sehingga dapat disimpulkan bahwa yang diajar dengan menggunakan metode time token arends lebih efektif terhadap hasil belajar teks eksposisi peserta didik dari pada yang diajar dengan metode pembelajaran time token arends dan metode pembelajaran mind mapping. Terlihat dari perolehan hasil nilai peserta didik yang menggunakan metode time token arends lebih tinggi dari pada menggunakan metode mind mapping yang kategori sedang

\section{SARAN}

Dalam penelitian ini terdapat beberapa saran yaitu kepada guru bahasa Indonesia agar dalam pembelajaran teks eksposisi disarankan untuk mengajar 
dengan menerapkan metode pembelajaran yang bervariasi, Kepada bidang pendidikan agar hasil penelitian ini dapat dijadikan bahan pertimbangan dalam rangka meningkatkan mutu pendidikan di Sekolah Menengah Atas, dan kepada peneliti lain jika mengkaji variabel yang sama, diharapkan untuk lebih menyempurnakan langkah-langkah metode dalam pembelajaran, dan dapat menerapkannya pada materi teks eksposisi.

\section{REFERENCES}

[1] Tarigan, Henry Guntur, 2008, Menulis, Bandung: Percetakan Angkasa.

[2] Mariyani, dkk, 2013, Pengaruh Implementasi Strategi Mind Mapping Terhadap Prestasi Belajar Menulis Kreatif Ditinjau Dari Kreativitas Siswa, e-Journal Program Pascasarjana Universitas Pendidikan Ganesha. 3.

[3] Dwinuryanti, dkk, 2018, Analisis Kohesi Gramatikal dan Leksikal pada Teks Eksposisi Siswa Kelas 10 Sekolah Menengah Atas, Jurnal Pendidikan dan Kebudayaan, 8 (1), 62.

[4] Mukrima, S. Syifa, 2014, 53 Metode Belajar dan Pembelajaran, Bandung. UPI.

[5] Huda, Miftahul, 2016, Model-model Pengajaran dan Pembelajaran, Yogyakarta: Pustaka Pelajar.

[6] Maesaroh, Siti, 2013, Peranan Metode Pembelajaran Terhadap Minat Dan Prestasi Belajar Pendidikan Agama Islam, Jurnal Kependidikan, 1 (1).

[7] Kalsum, Mardiah, 2017, Penggunaan Metode Pembelajaran Dalam Peningkatan Hasil Belajar Siswa, Jurnal Ilmiah Bidang Pendidikan, 11 (1).
[8] Lestari, Sri, 2009, Upaya Meningkatkan Keterampilan Menulis Siswa Dengan Pendekatan Kontekstual, Tesis, Surakarta: Program Pascasarjana UNS.

[9] Masbidin, 2018, Unsur Kebahasaan Eksposisi, Dapat diakses pada http://masbidin.net/teks-eksposisi/ (diunduh pada 7 Mei 2019).

[10] Creswell, John W, 2014, Research Design, Amerika Serikat: SAGE Publication.

[11] Sugiyono, 2015, Metode Penelitian Kuantitatif dan $R \& D$, Jakarta: Alfabeta.

[12] Oktorahardi, dkk, 2014. Pengggunaan Model Pembelajaran Kooperatif Tipe Time Token Arends dan Sumber Belajar Lingkungan untuk Meningkatkan Keterampilan Menulis Puisi Pada Siswa Kelas V SD Negeri 4 Sukomulyo, https://Jurnal.fkip.uns.ac.id (diunduh pada 6 Mei 2019).

[13] Yenidar, 2017, Penggunaan Metode Time Token Arends untuk Meningkatkan Keterampilan Berbicara pada Mata Pelajaran Bahasa Indonesia Peserta Didik Kelas IV SD Negeri 015 Sungai Rukam, Jurnal, 6 (2).

[14]Buzan, T., 2006, Buku Pintar Mind Map, Jakarta: PT. Gramedia Pustaka Utama.

[15] Hidayati, Qonita, 2017, Efektifitas Metode Mind Map (Peta Pikiran) dengan Media Gambar terhadap Hasil Belajar IPS Kelas III Semester II Materi Pokok Jenis-Jenis Pekerjaan di MIN Sumurrejo Semarang Tahun Pelajaran 2016/ 2017, Skripsi, Semarang: UIN Walisongo.

[16] Nurpratiwiningsih, Laelia, 2018, Development of Education Games Map Material as a Learning Media 
Jurnal SEMANTIKA, Volume 1, No. 01, Agustus 2019, p. 55-62

for Elementary School Students.

Jurnal of Primary Education. 7 (3),

Dapat diakses pada unnes.ac.id. 